\title{
Seton Application in Complex Perianal Fistula: Video Presentation
}

\section{Kompleks Perianal Fistülde Seton Uygulaması: Video Sunum}

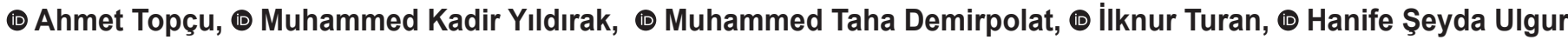 \\ University of Health Sciences Turkey, Ümraniye Training and Research Hospital, Clinic of General Surgery, İstanbul, Turkey
}

\section{HIIIIII| ABSTRACT}

Anal fistulas are non-physiological tract-like structures that open into the perianal skin starting from the distal rectum or anal canal and arise from abscesses on the basis of infection in the rudimentary glands around the dentate line. Recurrence rates vary between 10\%-50\% and this disease affects $2 \%$ of the society. Anal fistulas are classified as ischioanal, subanodermal, intersphincteric, transsphincteric, suprasphincteric, and extrasphincteric, and spontaneous remission is not possible in this disease. Physical examination, contrast enhanced pelvic magnetic resonance imaging and endoanal ultrasonography are used in the diagnosis of this disease, which presents with symptoms such as fever, fatigue, soiling and pain. In this clinical picture, which may also be associated with Crohn's disease, the ultimate treatment is surgery, and in this video presentation, we aimed to demonstrate a seton revision and tract curettage treatment in a patient who had previously undergone seton placement procedure for an extrasphincteric fistula.

Keywords: Complex perianal fistula, curettage, seton

\section{|IIIIIIII| ÖZ}

Anal fistüller distal rektum veya anal kanaldan başlayan perianal deride açılan fizyolojik olmayan trakt benzeri yapılardır ve dentate çizgideki rudimenter glandların enfeksiyonu zemininde gelişen apselerden kaynaklanırlar. Rekürrens oranları \%10-\%50 arasında değişmekte olup toplumun \%2'sini etkilemektedir. Anal fistüller iskioanal, subanodermal, intersfinkterik, transsfinkterik, suprasfinkterik ve ekstrasfinkterik olarak sinıflandırılmakta olup spontan remisyon bu hastalıkta söz konusu değildir. Ateş, genel durum bozukluğu, perianal akıntı gibi semptomlarla prezente olan bu hastalıkta tanıda fizik muayene, pelvik kontrastlı manyetik rezonans ve endoanal ultrasonografi kullanılmaktadır. Özellikle Crohn hastalığı ile de ilişkili olabilen bu klinik tabloda nihai tedavi cerrahi olup bu video prezentasyonda ekstrasfinkterik fistül nedeni ile daha önceden seton tedavisi uygulanmış bir hastada seton revizyonu ve trakt küretajı tedavisinin gösterilmesi amaçlanmıştır.

Anahtar Kelimeler: Karmaşık perianal fistül, küretaj, seton

\section{Introduction}

It has been shown in various sources that perianal fistula disease affects one out of every fifty people in the community. This disease usually has a chronic course despite treatment and causes recurrent hospital admissions due to recurrence. Because of the serious complications such as perianal abscess and sepsis, the negativities in the quality of life of the patient and the cost of treatment, clinicians have tried to optimize the treatment for various fistula types. ${ }^{1}$ Another type of fistula that is often associated with difficulties in treatment is extra-sphincteric fistula that usually requires more than one surgery. The long healing process is one of the most important morbidities in this disease, and various surgical interventions have been tried in order to accelerate the recovery and keep the patient's quality of life at the highest level. ${ }^{2}$ In this video presentation, it was aimed to demonstrate seton revision and fistula tract curettage in a patient who had previously undergone loose seton therapy due to extrasphincteric fistula. 
Written informed consent was obtained from the patient. Preoperative preparation was not made for the patient, except for a preoperative 6-hour fasting. Prophylactic antibiotic or enema was not administered. The patient was operated under general anesthesia in the gynecological dorsolithotomy position. The outer mouth of the extrasphincteric fistula at the 5 o'clock position was visualized. The inner mouth was found with the help of a stylet. The old seton was removed. The skin structure with pathological appearance in the outer mouth was excised up to the external anal sphincter and sent to pathology. The tract was curetted with gas soaked with oxygenated water and the operation was terminated by placing loose seton.

In conclusion, we think that loose seton application, especially internal curettage of the tract is a simple, comfortable surgical method that has a positive effect on healing, especially in sphincter-related or extrasphincteric fistula disease which has a chronic course and requires repeated surgical interventions.

* This video presentation was recorded at the proctology course held at University of Health Sciences Turkey, Ümraniye Training and Research Hospital on 17.10.2020.

\section{Informed Consent:}

Peer-review: Externally and internally peer reviewed.

\section{Authorship Contributions}

Surgical and Medical Practices: A.T., M.T.D, Concept: M.K.Y., Design: H.S.O., Data Collection or Processing: A.T., M.K.Y., Analysis or Interpretation: M.K.Y, A.T., H.S.U., Literature Search: M.T.D., M.K.Y. A.T., Writing: M.K.Y., A.T.

Conflict of Interest: No conflict of interest was declared by the authors.

Financial Disclosure: The authors declared that this study received no financial support.

\section{References}

1. Herold A, Lehur P, Matzel KE and O'Connell PR. Coloproctology, 2nd ed. Berlin, Germany: Springer 2017;59-73.

2. Steele SR, Hull TL, Read TR, Saclarides TJ, Senagore AJ and Whitlow CB. The ASCRS Textbook of Colon and Rectal Surgery, 3th ed. Arlington Heights, IL, USA: Springer 2016;215-244.

\section{Video 1.}

https://www.doi.org/10.4274/tjcd.galenos.2020. 2020-10-15.videol 